\title{
GRIMMIA BERINGIENSIS SP. NOVA (GRIMMIACEAE, BRYOPHYTA), A PUTATIVE CASE OF INTRAGENERIC HYBRIDIZATION
}

\author{
GRIMMIA BERINGIENSIS SP. NOVA (GRIMMIACEAE, BRYOPHYTA), \\ ВОЗМОЖНЫЙ МЕЖРОДОВОЙ ГИБРИД \\ ElenA A. IGNATOVA ${ }^{1}$, OXANA I. KuZNETSOVA ${ }^{2} \&$ MichaEL S. IGNATOV $^{1,2}$ \\ ЕЛЕНА А. ИГНАТОВА ${ }^{1}$, ОКСАНА И. КУЗНЕЦОВА ${ }^{2}$, МИХАИЛ С. ИГНАТОВ ${ }^{1,2}$
}

Abstract

\begin{abstract}
Molecular phylogenetic analysis of the nuclear ITS revealed four monophyletic entities within the group of species closely related to Grimmia leibergii-G. jacutuca, often considered within a separate genus Dryptodon. This group includes: (1) G. jacutica, widespread species in northern Asia and penetrating to Alaska in North America; (2) G. beringiensis, sp. nov., known from several localities in Chukotka; (3) G. arcuatifolia, a species of the northern part of the Pacific Northwest, from British Columbia to Alaska; and (4) G. leibergii, that occurs in a more southern range, from California to British Columbia. Three out of these four species fully agree with their position in Grimmia subg. Dryptodon (or genus Dryptodon), by morphology, ITS and also chloroplastic trnL, whereas G. beringiensis has trnL-F sequence almost identical with G. elatior from the subg. Grimmia. This is the second case of incongruence in topology between trees based on nuclear and chloroplastic markers in Grimmia s.l. It differs from the previous one, with $G$. tergestina, in that the putative hybridization involves a more distantly related taxa, sometimes classified in separate genera, Dryptodon and Grimmia. The broad circumscription of the Grimmia seems to be more appropriate to avoid nomenclatural problems.
\end{abstract}

Резюме

Анализ последовательностей ITS1-5.8S-ITS2 ядерной ДНК позволил выявить четыре независимых таксона среди образцов, относящихся к группе близких видов Grimmia leibergii-G. jacutuca, часто рассматриваемых в пределах рода Dryptodon. К этой группе относятся: (1) G. jacutica, широко распространеная на севере Азиатской России и проникающая на Аляску в Северной Америке; (2) $G$. beringiensis sp. nov., известная из нескольких местонахождений на Чукотке; (3) G. arcuatifolia, встречающаяся на севере западного побережья Северной Америки, от Британской Колумбии до Аляски; (4) G. leibergii, распространенная несколько южнее на западе Северной Америки, от Калифорнии до Британской Колумбии. Положение трех видов в Grimmia subg. Dryptodon (или в роде Dryptodon) вполне подтверждается их морфологическими особенностями, а также данными по последовательностям ITS ядерной ДНК и trnL-F хлоропластной ДНК; в то же время последовательности trnL-F у G. beringiensis оказались очень похожими на таковые у G. elatior. Это второй случай несогласованности топологий молекулярно-филогенетических деревьев, построенных по ядерным и хлоропластным маркерам, в роде Grimmia s.l. Предположительно этот таксон имеет гибридогенное происхождение, он образовался в результате гибридизации между не близкородственными видами, иногда относимыми даже к разным родам. Этот случай свидетельствует в пользу помещения всех видов в род Grimmia, что поможет избежать номенклатурных проблем.

KEYWORDS: Grimmia, mosses, ITS, trnL-F, infrageneric hybridization

\section{INTRODUCTION}

The genus Grimmia recently received a considerable attention of taxonomists. Three revisions were published in a world-wide scope (Muñoz \& Pando, 2000; Greven, 2003; Maier, 2010) and a number of regional treatments have covered expanded territories, including Russia (Ignatova \& Muñoz, 2004), Central Europe (Greven, 1995;
Maier \& Geissler, 1995), China (Cao et al., 2003), Japan (Deguchi, 1978), Himalayas (Maier, 2002, 2010), U.S.A. and Canada (Hastings \& Greven, 2007), Latin America (Muñoz, 1999b), and Neotropics (DelgadilloMoya, 2015)

In the course of the preparation of a taxonomic revision of the genus Grimmia in Russia, one species was

\footnotetext{
1 - Dept. of Geobotany, Faculty of Biology, M.V. Lomonosov’ Moscow State University, Moscow 119991 Russia - Pocсия 119991, Москва, Биологический факльтет Московского государственного университета им М.В. Ломоносова, каф. геоботаники; e-mail: arctoa@list.ru

2 - Tsitsin Main Botanical Garden of Russian Acad. Sci., Botanicheskaya 4, Moscow 127276 Russia - Россия 127276, Москва, ул. Ботаничекая 4, Главный ботанический сад им. Н.В. Цицина; e-mails: misha_ignatov@list.ru, oikuznets@gmail.com
} 
found to be undescribed, despite it is a quite widespread taxon. It was described under the name G. jacutica Ignatova, Bednarek-Ochyra, Afonina \& J. Muñoz (Ignatova et al., 2003). Its range covers ca. $4000 \mathrm{~km}$ in Siberia, from Yenisei River and Baikal Lake to Chukotka, and also penetrates to Alaska. At the same time, several collections from Chukotka were noticed as being somewhat different, approaching in some characters to G. leibergii Paris. The latter species was described from California and was though to be the closest relative of G. jacutica (Ignatova et al., 2003). The Chukotkan specimens, however, were left without taxonomic recognition of any level.

Hastings \& Greven (2007) reduced G. jacutica into the synonymy of $G$. leibergii, arguing that it is a very polymorphic species in Western North America, and characters separating it from G. jacutica are not enough stable to accept these species as distinct. On the other hand, E. Maier revised some collections of G. jacutica from Russia, including the holotype, and referred it to $G$. decipiens (Schultz) Lindb. (determinations in MW herbarium).

Finally, it is worthy mentioning that $G$. leibergii itself was for a long time treated as merely a synonym of G. trichophylla Grev. (Lawton, 1971; Anderson et al., 1990), a species that has 28 synonyms according to Muñoz \& Pando (2000).

Grimmia leibergii was resurrected from the oblivion by Muñoz (1999 a) together with another forgotten North American species, G. arcuatifolia Kindb., which is closely related to the former species. Hastings \& Greven (2007) accepted both $G$. leibergii and the species called by Muñoz G. arcuatifolia, although using another name for the latter, G. attenuata (Müll. Hal. \& Kindb.) Kindb. The usage of the earlier name $G$. arcuatifolia, was rejected because Hastings \& Greven (2007) referred it to G. lisae De Not., without any discussion. The illustrations of the type specimen of $G$. arcuatifolia presented by Muñoz (1999 a), however, better agree with the plants called $G$. attenuata by Hastings \& Greven (2007), rather than with G. lisae. In particular, the multistratose costa and, especially, thick-walled and porose basal juxtacostal cells are not characteristics of $G$. lisae. For this reason we follow Muñoz (1999a) in synonymization of G. attenuata with G. arcuatifolia and use of the latter name.

As the DNA sequences provide now a powerful method for solving taxinomic puzzles, we applied it to check which opinion corresponds more to the molecular barcoding patterns. In Grimmiaceae it was successfully applied to the whole family (Tsubota et al., 2003; Hernández-Maqueda et al., 2008b), Grimmia (HernándezMaqueda et al., 2008a, b; Streiff, 2006), Coscinodon (Ignatova et al., 2008), Schistidium (Goryunov et al., 2007; Ignatova et al., 2010; Milyutina et al., 2010), and Racomitrium (Larraín et al., 2013; Stech et al., 2013). We used ITS and $\operatorname{trn} \mathrm{L}-\mathrm{F}$ as markers, as they proved to be maximally useful in species-level taxonomy of Grimmiaceae in the above mentioned studies.

\section{MATERIAL AND METHODS \\ Sampling strategy}

The sampling was focused on rather confirming or rejecting the conclusions made by taxonomists using the classical morphological approach on the identity of Grimmia jacutica and G. leibergii. A number of specimens labeled with the latter name, however, appeared to represent two genetic entities at the stage of preliminary aligning. One of them, after additional studies, has been referred to G. arcuatifolia, which is morphologically similar and fairly confusing with $G$. leibergii. Thus we tried to obtain data for both of them.

Deviated Chukotkan plants, mentioned in the original description of $G$. jacutica, were represented by rather few samples. Available material for them was rather old, of 1970s, with few specimens of early 1980s, when Chukotka was actively explored by bryologists. DNA was successfully amplified only from three specimens, providing two sequences of ITS and two of trnL-F.

Specimen data and Gembank accession numbers are given in Appendix 1.

Total genomic DNA was extracted from herbarium specimens using the NucleoSpin Plant DNA extraction kit (Macherey-Nagel, Germany). The chloroplast trnL-F was amplified with primers C (CGA AAT CGG TAG ACG CTA CG) and F (ATT TGA ACT GGT GAC ACG $\mathrm{AG}$ ) and sequenced with the same primers (Taberlet et al. 1991). The nuclear ITS1-5.8S-ITS2 region was amplified with primer ITS1(CC GTA GGT GAA CCT GCG) and ITSB (GAT ATG CTT AAA CTC AGC CTA CG) and sequenced with the same primers. In cases of short reading, we additionally used internal primers: $\mathrm{p}$ 2(GCT GCG TTC TTC ATC GAT GC) and p3(GCA TCG ATG AAG AACGCA GC) for sequenced ITS1-5.8S-ITS2 region (White et al., 1990). PCR was conducted in $20 \mathrm{lL}$ aliquots containing 4 IL Ready-to-Use PCR MasterMIX based on 'hot-start' SmarTaq DNA polymerase (Dialat Ltd., Moscow, Russia), 13 lL deionized water, 5 pmol each primer and c. 1.5-2.0 ng template DNA in an MJ Research PTC-220 DNA Engine Dyad Thermal Cycler (BioRad Laboratories, Hercules, CA, USA). PCR program: for both region was the same: $94^{\circ} \mathrm{C}-3^{\prime}$ (initial denaturation), $58^{\circ} \mathrm{C}-30^{\prime \prime}, 72^{\circ} \mathrm{C}-1^{\prime}$; then 32 cycles: $94^{\circ} \mathrm{C}$ $-30^{\prime \prime}, 58^{\circ} \mathrm{C}-30^{\prime \prime}, 72^{\circ} \mathrm{C}-1^{\prime}$, and $72^{\circ} \mathrm{C}-5^{\prime}$ (final extension step). Amplification products were separated on a $1 \%$ garose gel in 19 TAE buffer with ethidium bromide staining and purified using the MinElute Gel Extraction Kit (Qiagen, Hilden, Germany). Purified PCR products were sequenced using the ABI PRISM BigDye Terminator v. 3. kit (Applied Biosystems) and further analysed on an ABI PRISM 3730 automated sequencer (Applied Biosystems, Waltham, MA, USA) at the 'Genom' Common Facilities Centre (Mocsow).

Sequences were aligned in Bioedit (Hall, 1999), using built-in aligning program ClustalW (Hall, 1999), with subsequent manual correction. 

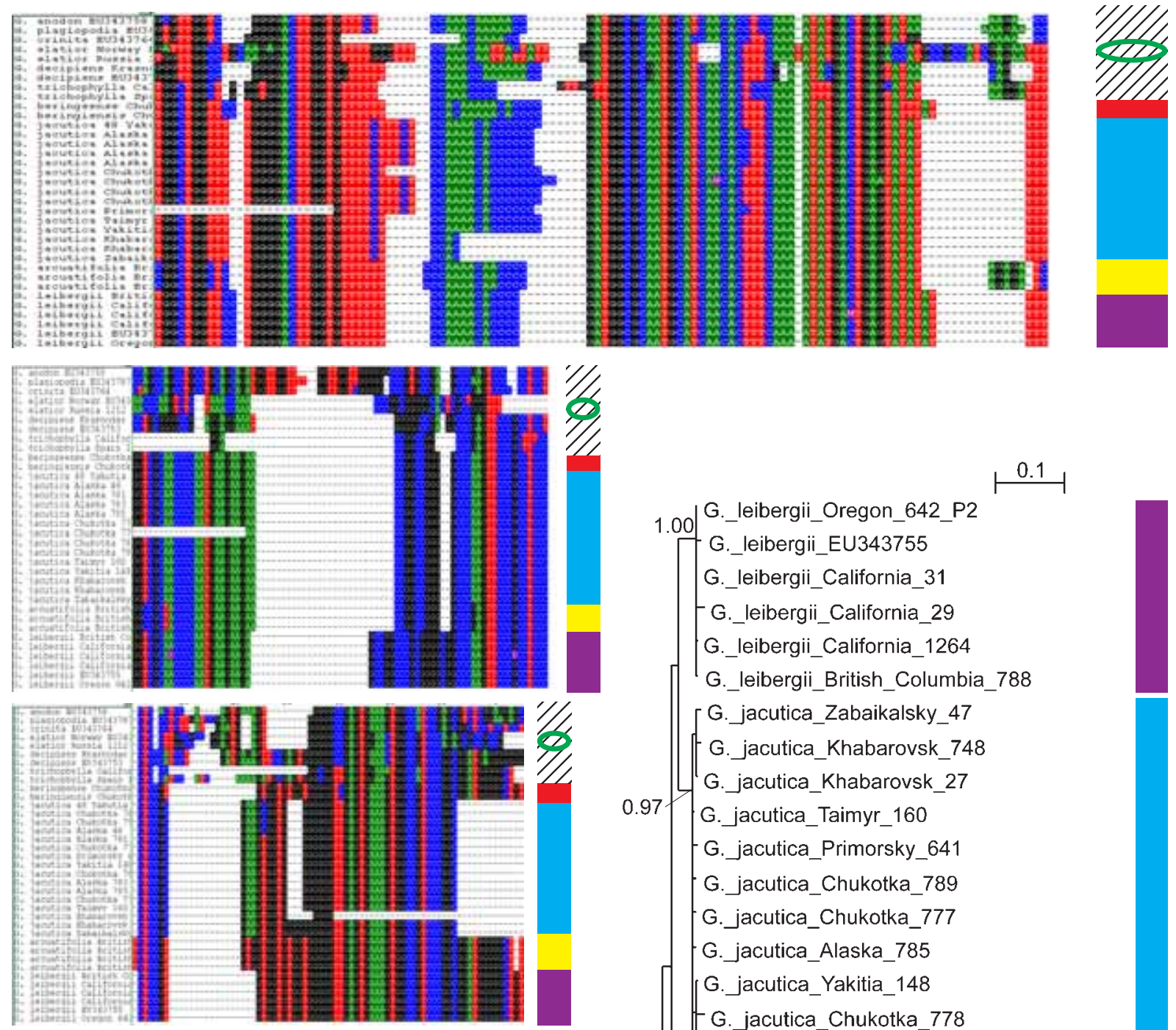

1.00 G._leibergii_Oregon_642_P2

G._leibergii_EU343755

G._leibergii_California_31

G._leibergii_California_29

G._leibergii_California_1264

G._leibergii_British_Columbia_788

[G.jjacutica_Zabaikalsky_47

G.jacutica_Khabarovsk_748

0.97

G._jacutica_Khabarovsk_27

G._jacutica_Taimyr_160

G._jacutica_Primorsky_641

G. jacutica Chukotka 789

G.jacutica_Chukotka_777

G._jacutica_Alaska_785

G. jacutica_Yakitia_148

- G.jacutica_Chukotka_778

G. jacutica_Alaska_783

G.jacutica_Alaska_781

Fig. 1. Parts of ITS sequence alignment of Grimmia jacutica - G. leibergii complex and the Baiesian phylogenetic tree. Red squares show the position of $G$. beringiensis and green ellipse indicates G. elatior.

\section{,}



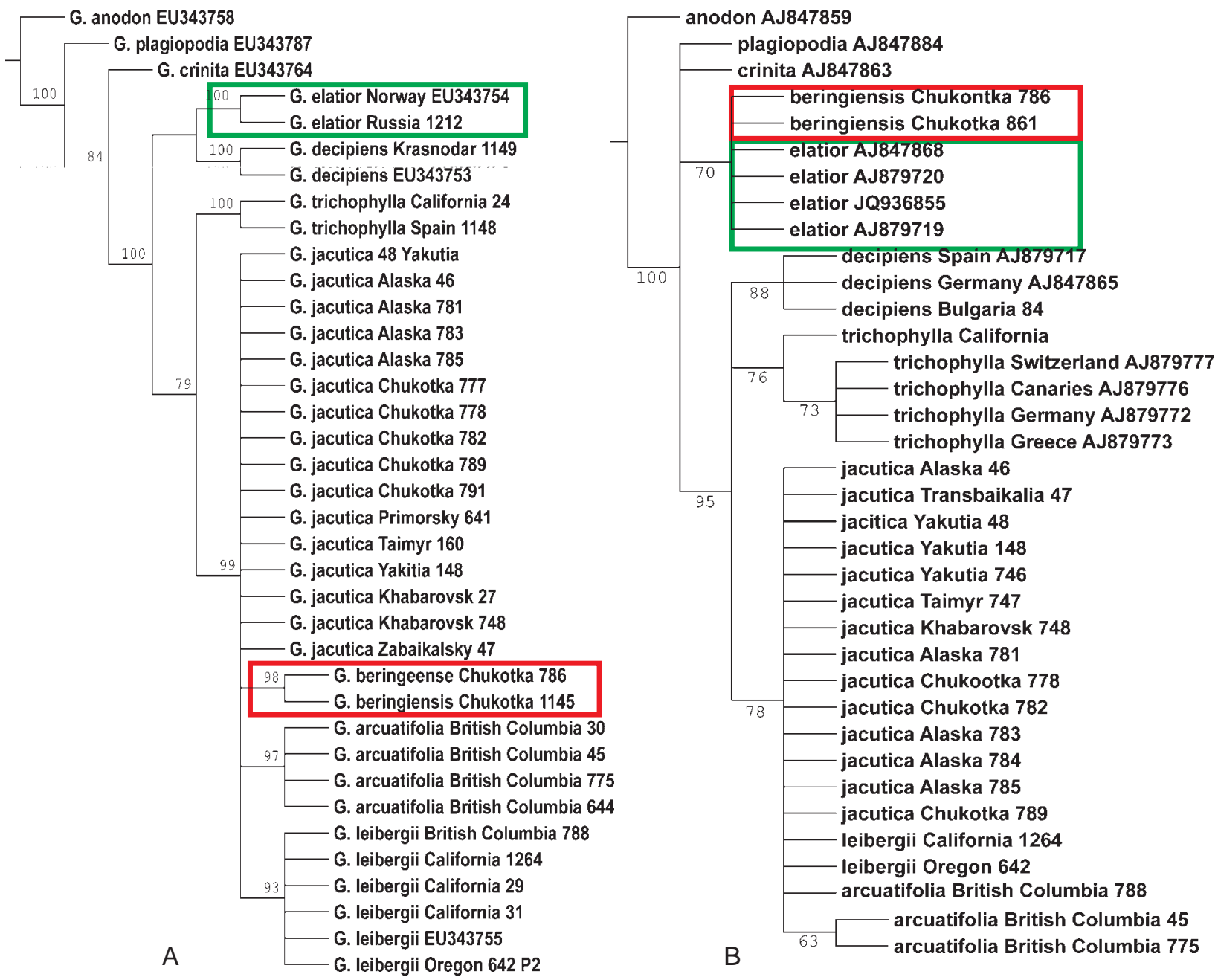

Fig. 2. Maximum parsimony phylogenetic trees based on nuclear ITS (A) and chloroplastic trnL-F sequences, and a part of $\operatorname{trn} \mathrm{L}-\mathrm{F}$ sequence alignment $(\mathrm{C})$ of Grimmia jacutica $-G$. leibergii complex. In the trees, red frames show the position of $G$. beringiensis and green of G. elatior. In the alignment, yellow frames separate Grimmia (above) and Dryptodon (below).

C

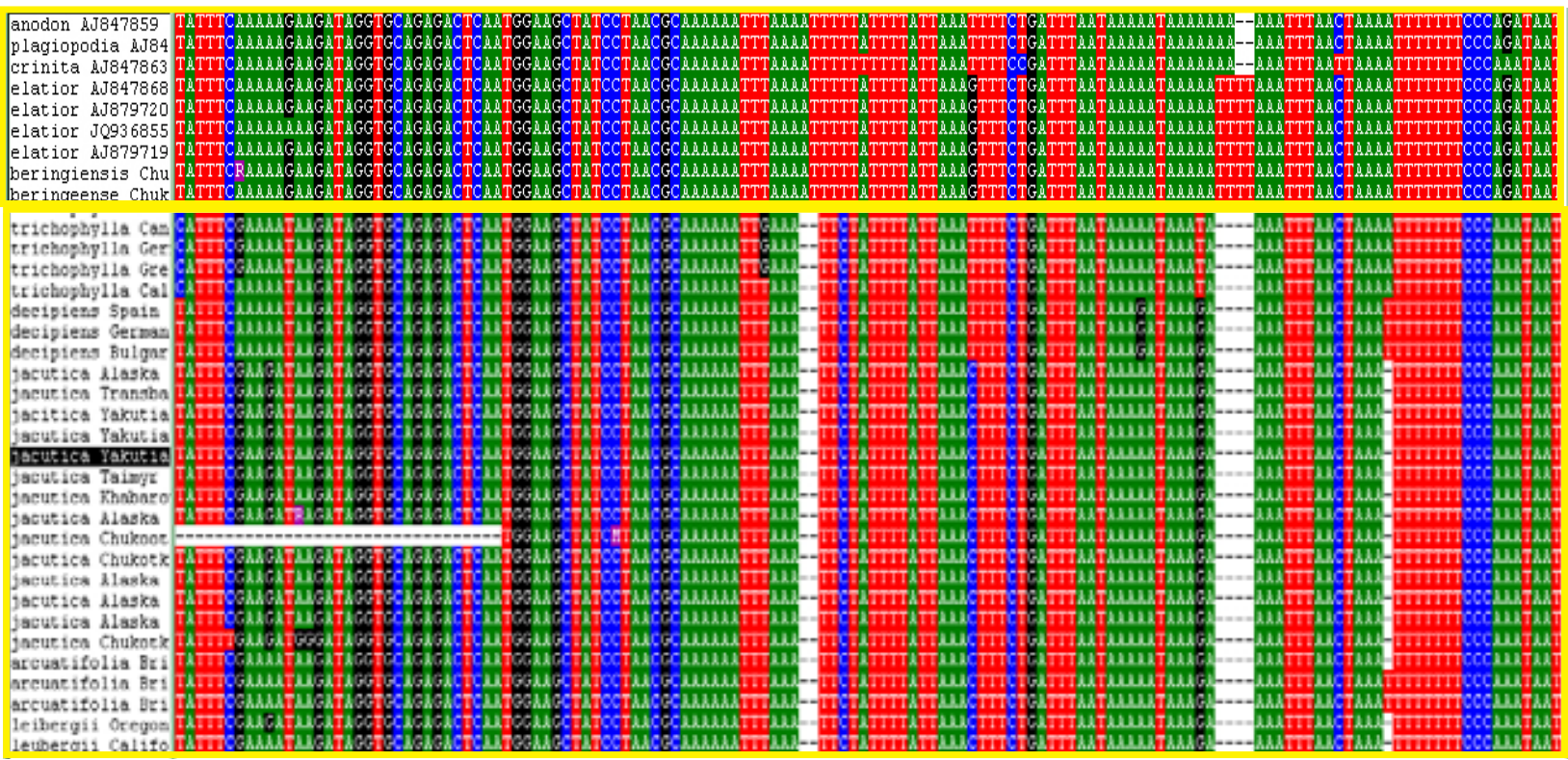


The incongruence in ITS and trnL-F became apparent from the preliminary alignments (Figs. 1-2), thus the analysis for these two regions was done independently. Trees for both regions were rooted on Grimmia anodon, and few other species were added, including $G$. decipiens and $G$. trichophylla (which were recently thought to be identical with G. jacutica and G. leibergii, correspondingly).

Maximum parsimony (MP) analyses were performed in Nona (Goloboff, 1994) in Winclada shell (Nixon, 1999). Gaps were treated as missing data, not coded. Bootstrap trees were calculated in Nona for 1000 iterations.

Bayesian analyses were conducted under a Bayesian Markov Chain Monte Carlo approach using MrBayes v.3.1.2 (Huelsenbeck \& Ronquist, 2001) with ITS divided into three partitions (ITS1, 5.8S rRNA, ITS2), with GTR +G +I model, for ITS1 and ITS2, and HKY+I model for 5.8S rRNA coding region. One compartment for the $\operatorname{trn} \mathrm{L}-\mathrm{F}$ region was analysed with $\mathrm{HKY}+\mathrm{I}$ model. The AIC criterion as implemented in MrModeltest 2.2 (Nylander, 2004) was used to determine the best fitting models. Three parallel runs were implemented, each with five chains and 10,000,000 generations ( $25 \%$ burnin), a "temp" parameter value of 0.15 and parameters unlinked between partitions.

\section{RESULTS}

Bayesian anayses (Fig. 1) found a maximal support for the group $G$. jacutica-G. leibergii. Moreover, the maximal support was obtained for clades composed of $G$. arcuatifolia, G. leibergii, and specimens from the Chukotka Peninsula (Fig. 1), and the high support was found also for $G$. jacutica $(\mathrm{PP}=0.97)$. The branch lengths for these four subclades were contrastingly shorter than the lengths for species, e.g. G. trichophylla and G. decipiens.

MP analyses of ITS (Fig. 2A) recovered a quite similar topology, with the high support $(\mathrm{BS}=99)$ for $\mathrm{G}$. jacutica-G. leibergii clade. This clade includes polytomy of specimens of $G$. jacutica and three nested clades, same as in Bayesian tree, i.e., G. arcuatifolia, G. leibergii, and specimens from the Chukotka Peninsula, with a rather high support ( $\mathrm{BS}=97,93$, and 98, corespondingly).

The trnL-F analyses, both Bayesian (not shown) and MP (Fig. 2B), resulted in the topology similar to ITS tree for almost all taxa, but with one exception. The Chukotkan specimens were found in common clade with Grimmia elatior Bruch ex Bals.-Criv. \& De Not. (with moderate support, $\mathrm{BS}=70$ ), not within $G$. jacutica-G. leibergii clade, where they were resolved in ITS analyses. At the same time, G. jacutica-G. leibergii-G. arcuatifolia clade was moderateloy supported $(\mathrm{BS}=78)$ in the MP analysis of trnL-F (Fig. 2B); and with G. decipiens and G. trichophylla it forms a larger clade of high support (BS=95).

Grimmia elatior was resolved in ITS analyses either in polytomy with $G$. decipiens and clade that includes $G$. trichophylla + G. jacutica-G. leibergii-clade (Fig. 1, ), or in unsupported clade with G. decipiens, and their common clade was sister to $G$. jacutica-G. leibergii clade + G. trichophylla (Fig. 2A). The latter topology was the same in $t r n \mathrm{~L}-\mathrm{F}$ analyses, with the only difference in the position of Chukotkan plants (Fig. 2A, as 'beringiensis'), which were sharing polytomy with specimens of $G$. elatior.

\section{DISCUSSION}

The first aim of the study was to solve the taxonomic status of G. jacutica and G. leibergii. Their close relationship was confirmed by this study, however, their distinction was greater than between $G$. jacutica and $G$. arcuatifolia (Bayesin tree in Fig. 1). Such situation would have two possible solutions: accepting a single species with three infraspecific taxa, or treating all three of them at the species level. We suggest the latter due to support from molecular phylogenetic analyses and the presence of morphological differences (Figs. 4-5, Table 1).

The Chukotkan plants, however, appeared to be much more interesting. A considerable incongruence between trnL-F and ITS datasets suggests its hybrid origin. ITS tree topology provided a strong signal that one of its ancestors is obviously a representative of the group of $G$. jacutica-G. leibergii. However, choosing one of the three species, G. jacutica, G. leibergii or G. attenuata as its most probable progenitor is not possible at present due to rather insufficient sampling.

The G. jacutica-G. leibergii group in the overall phylogeny of the genus Grimmia (Streiff, 2006; Hernandez-Maqueda et al., 2008a) was found within the G. trichophylla group, in a monophyletic clade sister to the genus Grimmia, which would support the segregation of the genus Dryptodon (Hernandez-Maqueda et al., 2008a).

However, the present $\operatorname{trn} \mathrm{L}-\mathrm{F}$ tree topology (Fig. 2 B), as well as the alignment (Fig. $2 \mathrm{C}$ ), indicate a quite remote position of the Chukotkan specimens from the $G$. jacutica-G. leibergii group. Instead, trnL-F sequences of the former are almost identical to G. elatior and also very similar to other species representing the main Grimmia clade by both Streiff (2006) and Hernandez-Maqueda et al. (2008 b). However, the variation of trnL-F marker is low within Grimmia, thus defining which would be the second putative ancestor is not clear.

The cases of reticulate evolution are not frequent in mosses, but already known in Grimmia. HernandezMaqueda et al. (2008a) found a similar incongruence in the position of Grimmia tergestina Tomm. ex Bruch et al. in chloroplast and ITS trees. The present case involves more distantly related groups (according to phylogeny of Hernandez-Maqueda et al., 2008a), often recognized as two genera, Grimmia and Dryptodon (Ochyra et al., 2003). A number of putative hybridogeneous species are known in Sphagnum (Cronberg \& Natcheva, 2002; Ricca \& Shaw, 2010), and a putative hybrid of taxa from different families has been found by Ignatov \& Milyutina (2011).

The practical suggestion from the present result on putative hybridization, is a warning against an acceptance of the genus Dryptodon. Thus the Chukotkan plants are described here in the genus Grimmia. 


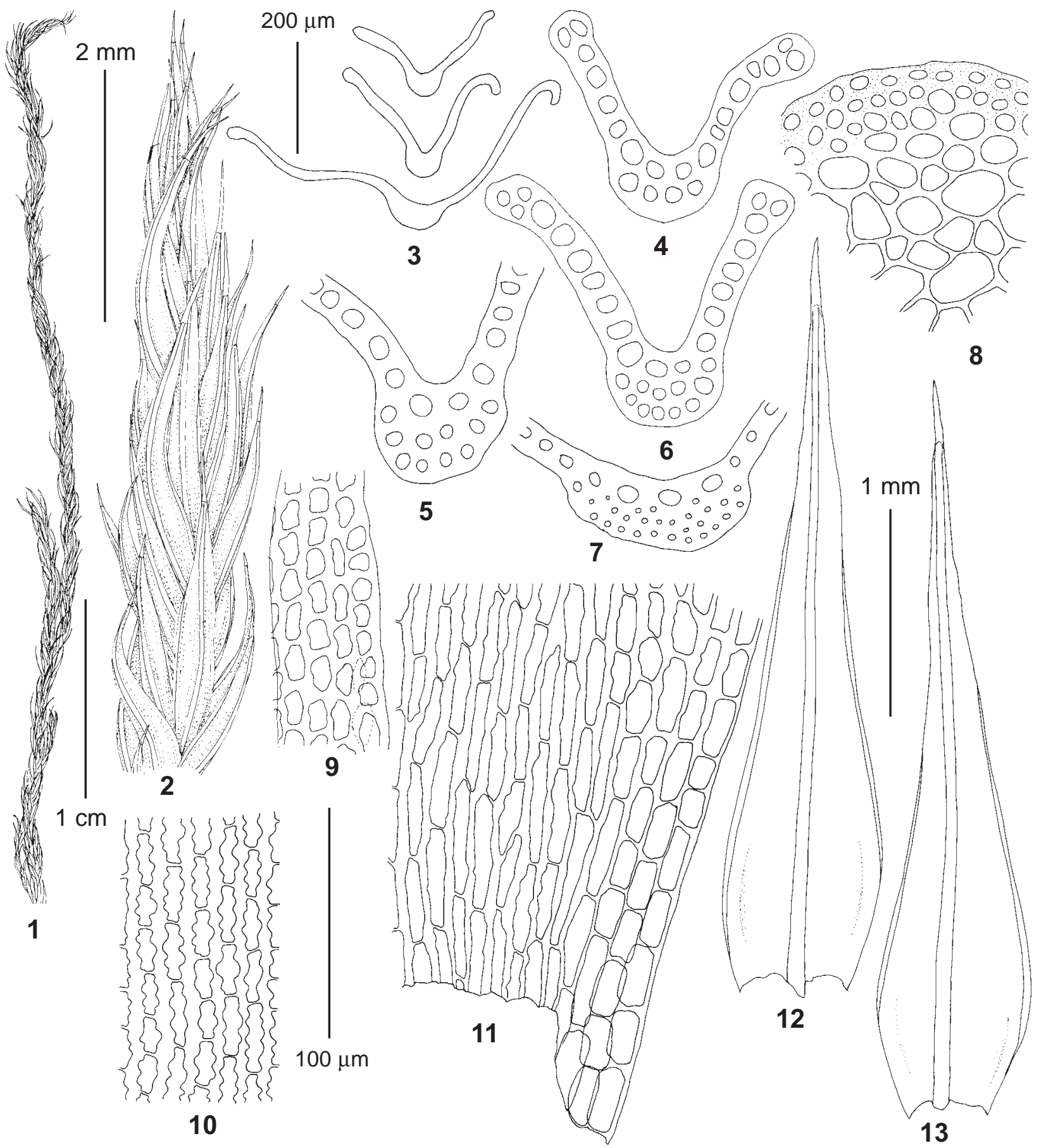

Fig. 3. Grimmia beringiensis Ignatova \& Ignatov (from holotype). 1, 2 - habit, dry; 3-7 - leaf transverse sections; 8 - stem transverse section; 9 - upper lamina cells; 10 - median lamina cells; 11 - basal lamina cells; $12-13$ - leaves. Scale bars: $1 \mathrm{~cm}$ for $1 ; 2 \mathrm{~mm}$ for $2 ; 1 \mathrm{~mm}$ for $12-13 ; 200 \mu \mathrm{m}$ for $3 ; 100 \mu \mathrm{m}$ for $4-11$.

TAXONOMY

Grimmia beringiensis Ignatova \& Ignatov, sp. nov. Figs. 3, 4 .

Similar to Grimmia jacutica, differs in appressed leaves with straight vs. recurved hair-points, costa (2-) 3-4-layered vs. 2-layered in transverse section and growing on soil among rocks in tundras vs. on rocks.

Type: Russia, south-east of Chukotka Peninsula, northern shore of Senyavin Strait near Yanrakynnot Set- tlement, rocky calcareous tundra with patchy Dryas and lichens, 23.VII.1976, Afonina s.n. (Holotype MW, Isotypes LE, MHA).

Plants medium-sized to large, growing in extensive, dense, but easily separating cushions, yellowishgreen at tips of shoots, brownish below, dull. Stems 2-8 cm, ascending to straight, sparsely branching, densely foliate, without central strand. Leaves appressed when dry, straight or slightly twisted around 
Table 1. Some diagnostic morphological characters of Grimmia (Dryptodon) species with costa reniform in cross-secion and arcuate seta.

Species

leaf lamina length, mm

hair-point length, mm,

decurrency

and serration

costa width at base, $\mu \mathrm{m}$

number of cell

layers in costa:

distal

median

basal

cell wall thickness

cell size, $\mu \mathrm{m}$ :

distal, width

distal, length

median, width

median, length

basal juxtacostal

cell walls

basal marginal

transverse cell walls thick

sexual condition

sporophyte frequency

\section{G. jacutica}

$2-2.5$

$0-0.5$

decurrent

fine, distant

60-85

\begin{abstract}
2
\end{abstract}
2

2

strong

7-12

9-25

8.5-12

12-30

thick,

porose

thick

dioicous

rare
G. beringiensis

2-3

$0-0.8$

decurrent

fine, distant

50-75

2-3

3

3-4

strong

8-13

13-25

9-13

18-33

thick,

porose

thick

dioicous

unkmown
G. leibergii

\section{2-3.1}

0.45-1.1

decurrent

fine, distant

80-100

2

3

3-4

median

5.5-8.5

$7-15$

7-10.5

9-20

thick,

porose

thick

dioicous

frequent
G. arcuatifolia $G$. decipiens

3-3.5

0-0.45

not decurrent

sharp, distant

130-175

$2.5-3$

$0.5-1.5$

decurrent

strong, dense

60-70

G. lisae

$1.5-2$

$0-0.5$

decurrent

sharp, dense

50-75

$3(-4)$

$3(-4)$

4-5

median

median

median

\section{$7-9.5$}

$6-12$

$7-11$

7.5-15(-20)

thick,

porose

9-13

$10-14$

$9-12$

$15-25$

$5-7$

$4-9.5$

$5-8.5$

$9-16$

thick,

porose

thin,

not porose

thin

dioicous

thick

thick

autoicous

dioicous

rare the stem, erecto-patent when wet, lamina 2-3 mm long, $0.45-0.6 \mathrm{~mm}$ wide, narrowly lanceolate; hair-points $0-0.6(-0.8) \mathrm{mm}$ long, with very short distant spinulae to almost smooth, short to long decurrent; costa 50 $75 \mu \mathrm{m}$ wide at leaf base, moderately projecting dorsally, reniform in transverse section, with 3-6 cells exposed on ventral surface, 2-3-layered distally, 3layered in mid-leaf and 3-4-layered at base; margin recurved in proximal 2/3-3/4 on one side of leaf and shorter recurved on the other side, plane and slightly uneven distally; lamina smooth, unistratose except one bistratose marginal or submarginal row of cells; distal lamina cells rectangular, (12-)15-25(-28) $\mu \mathrm{m}$ long and (8-) $10-12(-13) \mu \mathrm{m}$ wide, thick-walled, walls slightly sinuose; median lamina cells elongate-rectangular, (18-)21-30(-35) $\mu \mathrm{m}$ long and 9-11(-13) $\mu \mathrm{m}$ wide, with strongly thickened and strongly sinuose longitudinal walls and thin transverse walls; basal juxtacostal cells linear, $12-13 \mu \mathrm{m}$ wide and 30-50(-70) $\mu \mathrm{m}$ long, thick-walled and porose, basal marginal cells short rectangular, with thickened transverse walls, occasionally pellucide. Sexual condition dioicous, gametangia lateral. Sporophytes unknown.

Specimens examined: RUSSIA: Chukotka: Yanrakynnot Settlement surroundings, 20.VII.1976, Afonina s.n. (LE, MW); Ushkligran Settlement outskirts, 6.VII.1970, Afonina s.n. (LE, MW); NW shore of Penkigney Bay near Peszovaya Creek mouth, 11.VII.1978, Afonina s.n. (LE, MW).

Distribution and ecology. The species was collected in several rather close localities in south-eastern Chukotka. It grows at low altitudes not far from sea coast, on soil in rocky tundras in an area with calcareous bedrocks, along patchy Dryas communities with extensive moss and lichen cover; it was also once collected in Alnus fruticosa stands on calcareous slopes of a hill.

Differentiation. Leaves of $G$. beringiense are slightly longer than those of G. jacutica, with lamina length up to $3 \mathrm{~mm}$ vs. to $2.5 \mathrm{~mm}$. Its hair-point length and decurrency, and lamina areolation are very similar or practically identical with G. jacutica (Fig. 4, see also illustrations in Ignatova et al., 2003). However, these two species can be recognized with a hand-lens or under stereomicroscope by their different leaf arrangement and hairpoint orientation: leaves are straight, occasionally only slightly twisted and with straight hair-points in $S$. beringiense, while in G. jacutica laeves are often secund and usually have hair-points recurved at right angle, resembling Racomitrium laetum in this character. Furthermore, Grimmia jacutica grows mostly on rocks, often on and between boulders of rock-fields, whereas $G$. beringiensis was collected on soil in tundras. Plants of G. jacutica are in most cases yellowish-olivaceous in a considerable distal portion, whereas plants of $G$. beringiensis have only uppermost leaves yellowish-green and with most part of the shoots brown. Among microscopic characters, costa transverse section alone is important, being always bistratose throughout in G. jacutica and 3-4-stratose in $G$. beringiensis at least at leaf base.

Grimmia beringiensis differs from G. leibergii in considerably larger laminal cells with much thicker longitudinal walls (Table 1, Figs. 4-5). Costa of G. leibergii is 3-4-stratose in transverse section, like in $G$. beringien- 


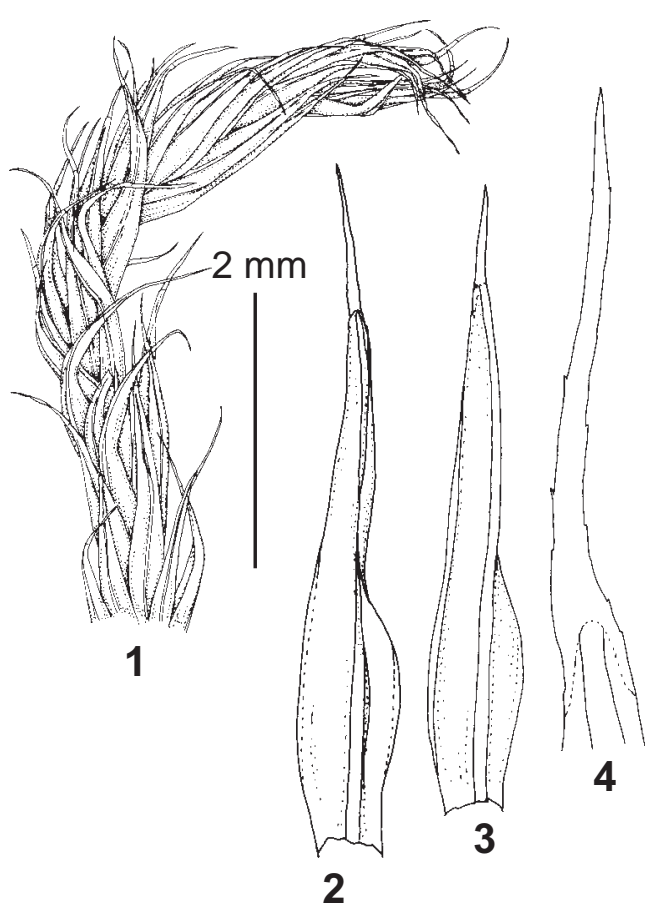

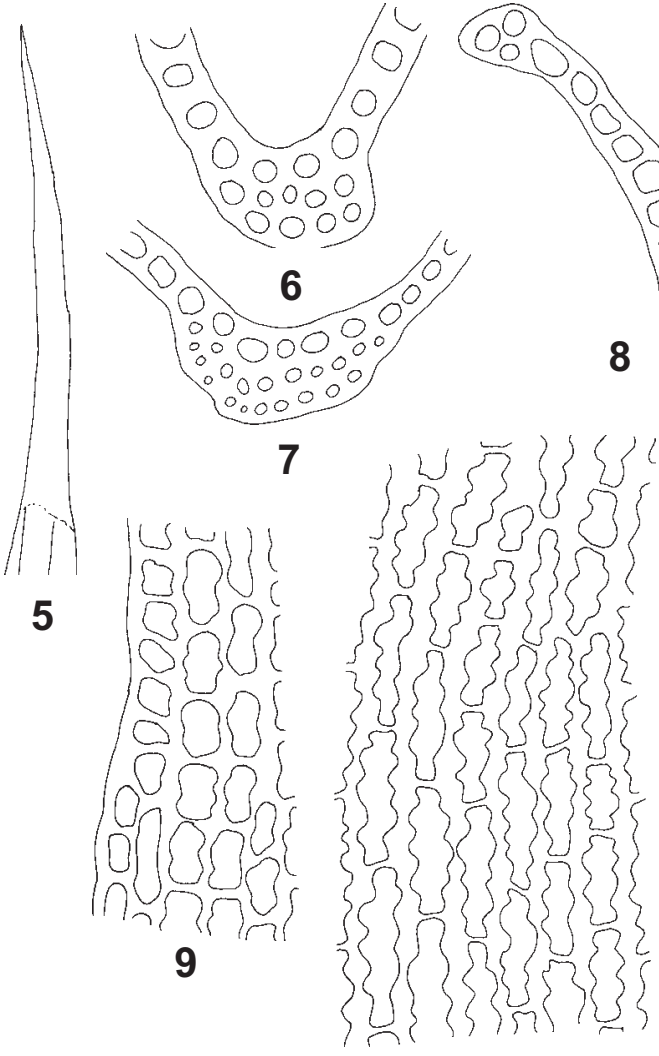

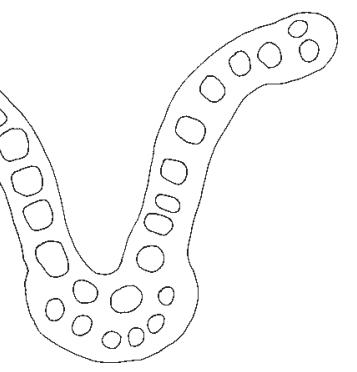

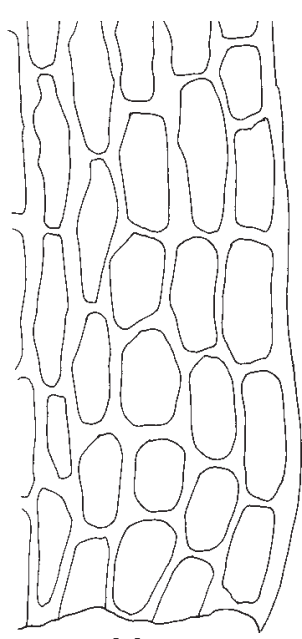

11
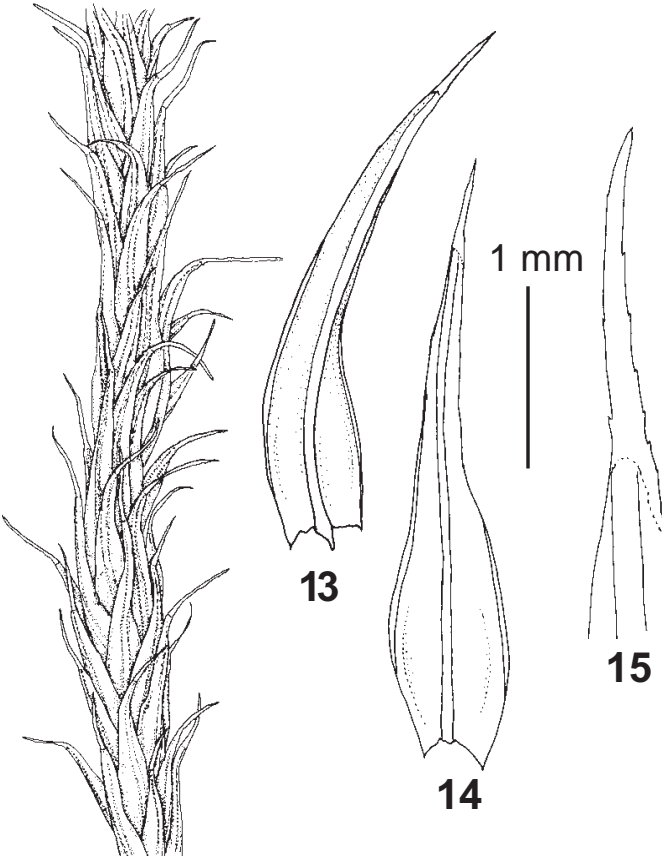

12

Fig. 4. 1-11-Grimmia beringiensis (from holotype); 12-22-G. jacutica (from: Russia, Yakutia, Ignatov \& Ignatova 11-3442, MW). 1, 12 - habit, dry; 2-3, 13-14- leaves; 4-5, 15-16-hair-points; 6-8, 17-19- leaf transverse sections; 9, 20- upper lamina cells; 1021 - median lamina cells; 1122 - basal marginal cells. Scale bars: $2 \mathrm{~mm}$ for 1 , 12 ; $1 \mathrm{~mm}$ for $2-3,13-14 ; 0.5 \mathrm{~mm}$ for $4-5,15-16$; $50 \mu \mathrm{m}$ for $6-8,17-19 ; 100 \mu \mathrm{m}$ for $9-11,20-22$.

10
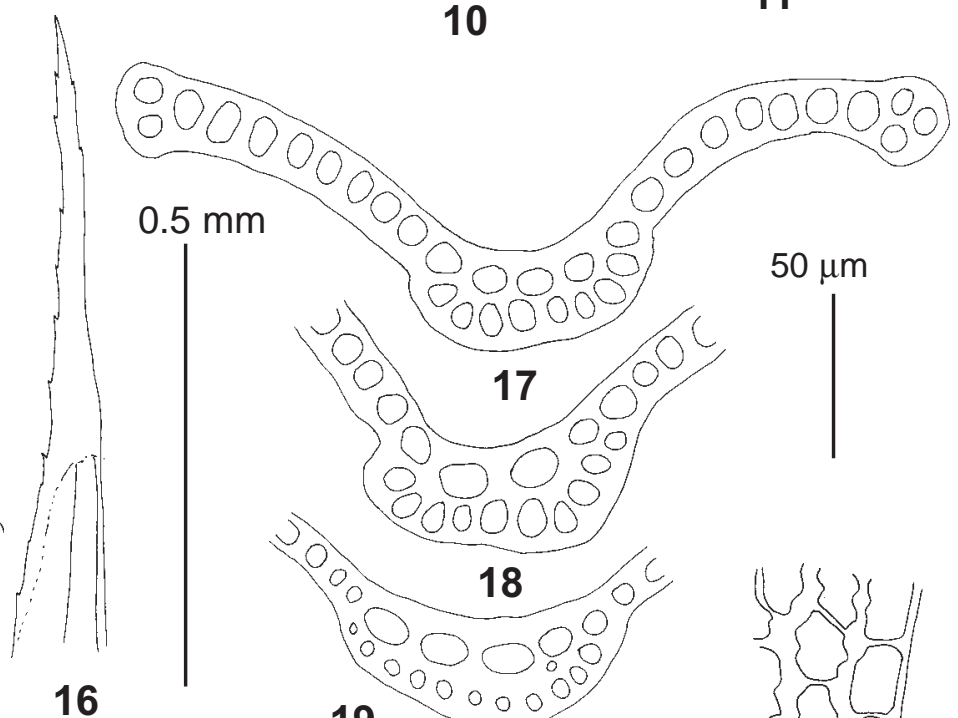

16

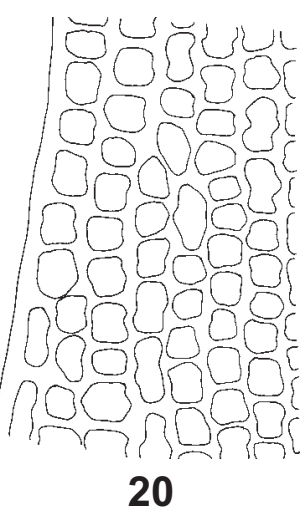

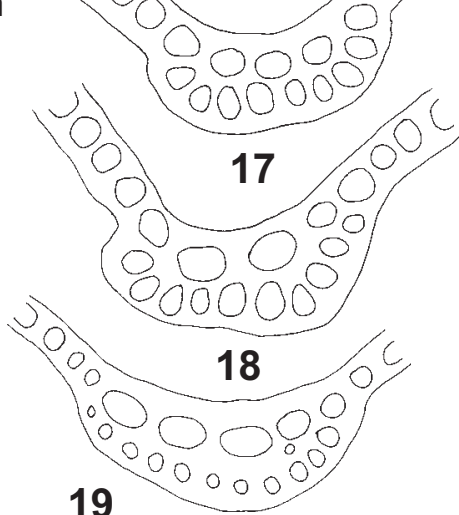

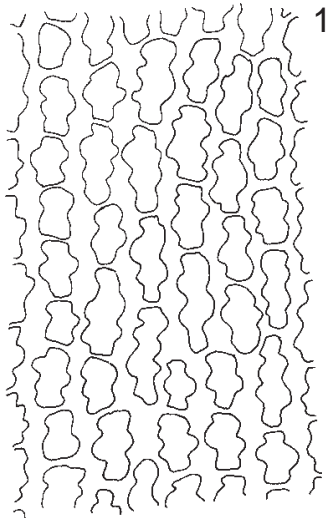

21
$50 \mu \mathrm{m}$

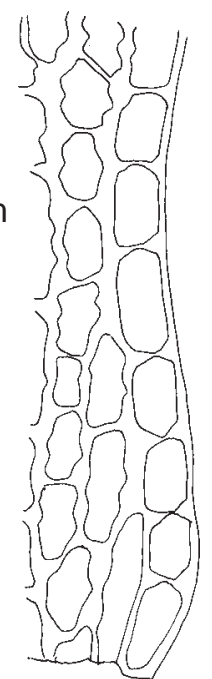

22 


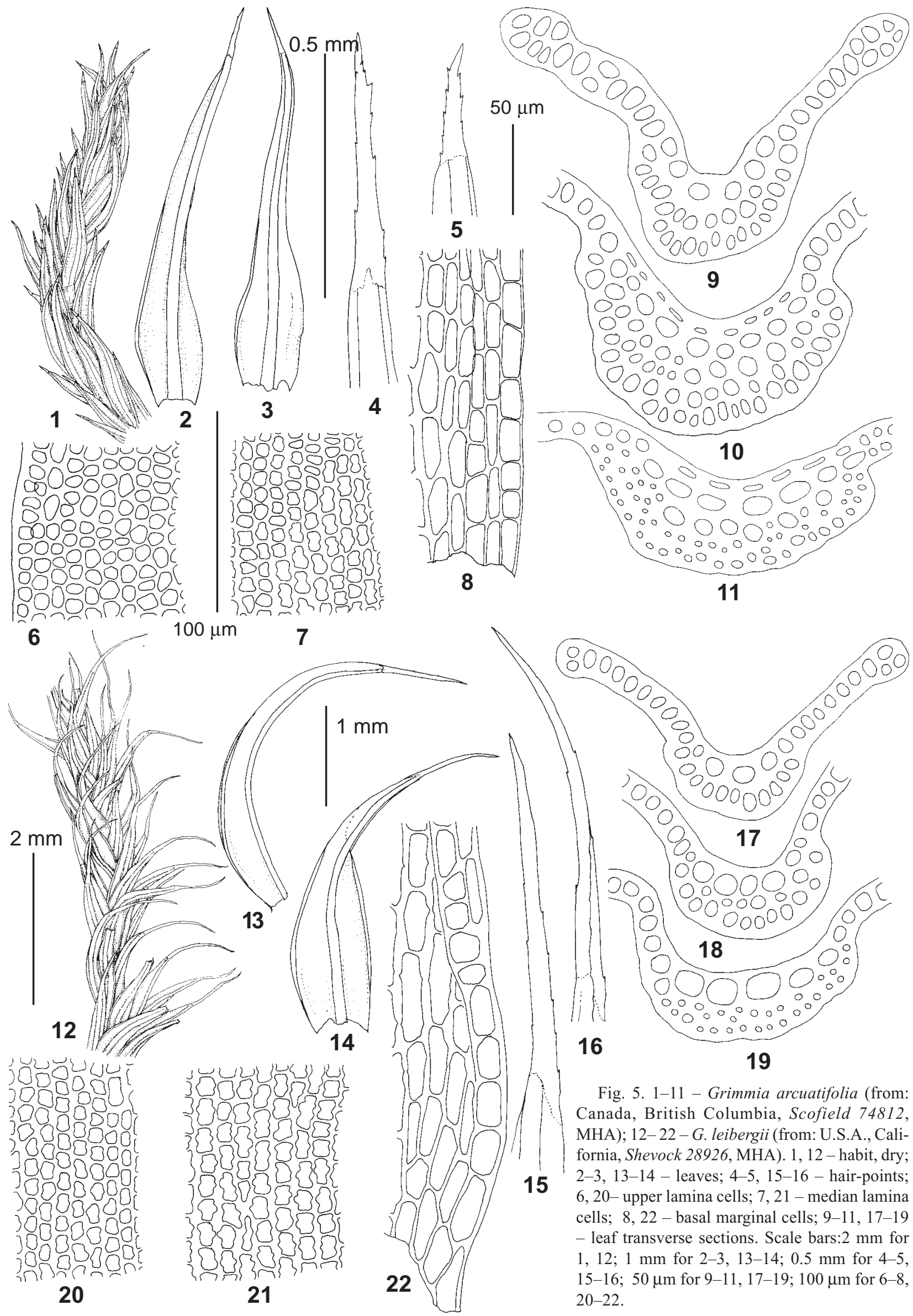


sis, but it is much wider in the former species, $80-100 \mu \mathrm{m}$ vs. 50-75 $\mu \mathrm{m}$, with greater number of cells on ventral surface and stronger differentiated ventral surface cells (Figs. 4-5). In addition, falcate-secund leaves, the plants usually fertile, and the dark-green colored plants, make G. leibergii contrastingly different from the brown plants with straight leaves of $G$. beringiensis, which sporophytes are still unknown.

Grimmia attenuata superficially resembles G. beringiensis in shoots with straight and appressed leaves and straight hair-points, but these two species have strikingly different lamina areolation (see Figs. 4-5 and Table 1). The exceedingly strong costa of $G$. attenuata, very wide (130-175 $\mu \mathrm{m}$ at base) and 3-5-stratose, the non-decurrent hair-ponts, and the thin-walled basal marginal cells, are the features distinguishing it from all three other species of this group.

The differences between $G$. beringiensis and $G$. decipiens include finely and distantly vs. sharply and densely serrate hair-points, straight vs. falcate leaves, 3-stratose vs. 2-stratose costa and strongly vs. moderately thickened cell walls. Grimmia lisae differs from G. beringiensis in the smaller size of plants and leaves, strongly recurved vs. erecto-patent leaves in wet condition, and basal juxtacostal cells with thin and non porose walls vs. thick and strongly porose walls. Both $G$. decipiens and G. lisae were only recently found in Russia (Doroshina et al., 2015; Bezgodov et al., 2016), and each of them is known from a single locality at the Black Sea coastal area in the West Caucasus.

\section{ACKNOWLEDGMENTS}

We are greatly indebted to O.M. Afonina for the disposal of her collections for our study and to W.C. Schofield, J.R. Shevock and J. Kučera for sending us duplicates of Grimmia specimens. Authors cordially thank Dr. Juan B. Larraín for valuable comments on the manuscript and a language check. The present study was supported by RFBR Project \#15-29-02647.

\section{LITERATURE CITED}

ANDERSON, L. E., H.A. CRUM \& W.R. BUCK. 1990. List of mosses of North America north of Mexico. - Bryologist 93: 448-499.

BEZGODOV, A.G., E.A. IGNATOVA \& M.S. IGNATOV. 2016. New moss records in Krasnodar Terrritory. 10. - In: Sofronova E.V. (ed.). New bryophyte records. 6. Arctoa 25: 216.

CAO, T., S. HE \& D.H. VITT. 2003. Grimmiaceae. - In.: He, S. (ed.) Moss flora of China, vol. 3. Beijing, New York, Science Press \& St. Louis, Missouri Bot. Garden Press: 3-76.

CRONBERG N. \& R. NATCHEVA. 2002. Hybridization between the peat mosses, Sphagnum capillifolium and S. quinquefarium (Sphagnaceae, Bryophyta) as inferred by morphological characters and isozyme markers. - Plant Systematics and Evolution 234(1/4): 53-70.

DEGUCHI, H. 1978. A revision of the genera Grimmia, Schistidium and Coscinodon (Musci) of Japan. - Journal of Science of the Hiroshima University, Series B, Division 2 (Botany): 16: 121-256.

DELGADILLO-MOYA, C. 2015. Grimmia (Grimmiaceae, Bryophyta) in the Neotropics. - http://www.ibiologia.unam.mx/barra/publicaciones/ Grimmia-\%20web3-fin.pdf (accessed 1May 2016).
[DOROSHINA, G.YA., E.A. IGNATOVA \& L.E. KURBATOVA] ДОРОШИНА Г.Я., Е.А. ИГНАТОВА, Л.Е. КУРБАТОВА. 2015. Новые находки мхов в Краснодарском крае. 9. - [New moss records from Krasnodar Territory. 9] In: Sofronova, E.V. (ed.). New Bryophyte Records. 5. Arctoa 24: 603-604.

GOLOBOFF, P.A. 1994. NONA: A Tree Searching Program. Program and documentation. - Argentina, Tucumán, published by the author.

GORYUNOV D.V., E.A. IGNATOVA, M.S. IGNATOV, I.A. MILYUTINA \& A.V. TROITSKY. 2007. Support from DNA data for a narrow species concept in Schistidium (Grimmiaceae, Musci). - Journal of Bryology 29: 98-103.

GREVEN, H.C. 1995. Grimmia Hedw. (Grimmiaceae, Musci) in Europe. - Leiden, Backhuys Publishers, 160 pp.

GREVEN, H.C. 2003. Grimmias of the world. - Leiden, Backhuys Publishers, $247 \mathrm{pp}$.

HALL, T.A. 1999. BioEdit: a user-friendly biological sequence alignment editor and analysis program for Windows 95/98/NT. - Nucleic Acids Symposium Series 41: 95-98.

HASTINGS, R.I. \& H.C. GREVEN. 2007. Grimmia.-In: Flora of North America Editorial Committee (eds.) Flora of North America North of Mexico. Vol. 27: 225-258.

HERNÁNDEZ-MAQUEDA, R., D. QUANDT \& J. MUÑOZ. 2008a. Testing reticulation and adaptative convergence in the Grimmiaceae (Bryophyta). - Taxon 57: 500-510.

HERNÁNDEZ-MAQUEDA, R., D. QUANDT, O. WERNER \& J. MUÑOZ. 2008b. Phylogeny and classification of the Grimmiaceae/ Ptychomitriaceae complex (Bryophyta) inferred from cpDNA. - Molecular Phylogenetics and Evolution 46: 863-877.

HUELSENBECK, J., \& F RONQUIST. 2001. MRBAYES: Bayesian inference of phylogenetic trees. - Bioinformatics 17: 754-755.

IGNATOV, M.S. \& I.A. MILYUTINA. 2011. Intrafamilial hybridization in mosses? An enigmatic case in the genus Podperaea (Hypnales, Bryophyta). - Arctoa 20: 107-118.

IGNATOVA, E. \& J. MUÑOZ. 2004. The genus Grimmia (Grimmiaceae, Musci) in Russia. - Arctoa 13: 100-182.

IGNATOVA, E., H. BEDNAREK-OCHYRA, O. AFONINA \& J. MUÑOZ. 2003 [2004]. A new species of Grimmia (Grimmiaceae, Musci) from north-east Asia and Alaska. - Arctoa 12: 1-8.

IGNATOVA, E.A., H.H. BLOM, D.V.GORYUNOV \& I.A. MILYUTINA. 2010. On the genus Schistidum (Grimmiaceae, Musci) in Russia. - Arctoa 19: 195-233.

IGNATOVA E., O. KUZNETZOVA, H. KÖCKINGER \& R. HASTINGS. 2008. A preliminary study of Coscinodon (Grimmiaceae, Musci) in Eurasia based on moprphology and DNA sequence data. - Arctoa 17: 1-18.

LARRAÍN J., D. QUANDT, M. STECH \& J. MUÑOZ. 2013. Lumping or splitting? The case of Racomitrium (Bryophytina: Grimmiaceae). Taxon 62: 1117-1132.

LAWTON, E. 1971. Moss flora of the Pacific North-West. - Hattori Botanical Laboratory, Nichinan, $62 \mathrm{pp} .+195 \mathrm{pl}$.

MAIER, E. 2002. The genus Grimmia (Musci, Grimmiaceae) in Himalaya. - Candollea 57: 143-238.

MAIER, E. 2010. The genus Grimmia Hedw. (Grimmiaceae, Bryophyta): A morphological-anatomical study. - Boissiera 63: 1-377.

MAIER, E. \& P. GEISSLER. 1995. Grimmia in Mitteleuropa: ein Bestimmungsschlüssel - Herzogia 11: 1-80.

[MILYUTINA, I.A., D.V. GORYUNOV, M.S. IGNATOV, E.A. IGNATOVA \& A.V. ТROITSKY] МИЛЮТИНА И.А., Д.В. ГОРЮНОВ, М.С. ИГНАТОВ, Е.А. ИГНАТОВА, А.В. ТРОИЦКИЙ. 2010. Филогения мхов рода Schistidium (Bryophyta, Grimmiaceae) по нуклеотидным последовательностям и вторичной структуре внутренних транскрибируемых спейсеров ядерной рДНК. - [The phylogeny of Schistidium (Bryophyta, Grimmiaceae) based on the primary and secondary structure of nuclear rDNA internal transcribed spacers] Молекулярная биология [Molecular biology] 44(6): 994-1009. 
MUÑOZ, J. 1999a. Grimmia arcuatifolia and G. leibergii (Musci, Grimmiaceae), two neglected species from northwestern North America. Anales del Jardín Botánico de Madrid 57(1): 7-13.

MUÑOZ, J. 1999b. A revision of Grimmia (Musci, Grimmiaceae) in the Americas. 1: Latin America. - Annales of Missouri Botanical Garden 86: $118-191$.

MUÑOZ, J. \& F. PANDO. 2000. A world synopsis of the genus Grimmia. - Monographs in Systematic Botany from the Missouri Botanical Garden 83: 133 pp.

NIXON, K.C. 1999. Winclada (BETA) ver. 0.9.9. available at http:// Www.cladistics.com/about_winc.html.

NYLANDER, J.A.A. 2004. MrModeltest. - Evolutionary Biology Centre, Uppsala University.

OCHYRA, R., J. ŻARNOWIEC \& H. BEDNAREK-OCHYRA. 2003. Census catalogue of Polish mosses. - Polish Acad. Sci., Inst. Bot., Krakow, $372 \mathrm{pp}$.

RICCA, M. \& A.J. SHAW. 2010. Allopolyploidy and homoploid hybridization in the Sphagnum subsecundum complex (Sphagnaceae: Bryo- phyta). - Biological Journal of the Linnean Society 99(1): 135-151. STECH, M., S. VELDMAN, J. LARRAÍN, J. MUÑOZ, D. QUANDT, K. HASSEL \& H. KRUIJER. 2013. Molecular species delimitation in the Racomitrium canescens complex (Grimmiaceae) and its implications for DNA barcoding of species complexes in mosses. - PLoS ONE 8, e53134.

STREIFF, A. 2006. Phylogenetic study of Grimmia (Grimmiaceae) based on plastid DNA sequences ( $\operatorname{trn} \mathrm{L}-t r n \mathrm{~F}$ and $r p s 4$ ) and on morphological characters. - Bryologist 109: 224-235.

TABERLET, P., L. GIELLY, G. PAUTOU \& J. BOUVET. 1991. Universal primers for amplification of three non-coding regions of chloroplast DNA. - Plant Molecular Biology 17: 1105-1109.

TSUBOTA, H., Y. AGENO, B. ESTÉBANEZ, T. YAMAGUCHI \& H. DEGUCHI. 2003. Molecular phylogeny of the Grimmiales (Musci) based on chloroplast $r b c L$ sequences. - Hikobia 14: 55-70.

WHITE, T.J., T. BRUNS, S. LEE \& J. TAYLOR. 1990. Amplification and direct sequencing of fungal ribosomal RNA genes for phylogenetics. - In: Innis, M., D. Gelfand, J. Sninsky \& T. White (eds.), PCR Protocols: A Guide to Methods and Applications. Academic Press, San Dieg: 315-322.

Appendix 1. Species of Grimmia, used for molecular phylogenetic analysis of nrITS and cp trnL-F.

\begin{tabular}{|c|c|c|c|c|}
\hline & & & ITS & $\operatorname{trn} \mathrm{L}-\mathrm{F}$ \\
\hline arcuatifolia & British Columbia 30 & Canada, British Columbia, Schofield \& Spence 84310 (MHA) & KX443539 & - \\
\hline G. arcuatifolia & British Columbia 643 & $\begin{array}{l}\text { Canada, British Columbia, Schofield \& Djan-Chekar } \\
104960 \text { (MHA) }\end{array}$ & KX443542 & - \\
\hline G. arcuatifolia & British Columbia 644 & Canada, British Columbia, Schofield 77506 (MHA) & KX443545 & - \\
\hline G. arcuatifolia & British Columbia 775 & Canada, British Columbia, Scofield 74812 (MHA) & KX443540 & KX443514 \\
\hline G. arcuatifolia & British Columbia 45 & $\begin{array}{l}\text { Canada, British Columbia, Schofield \& Djan -Chekar } \\
104960 \text { (MHA) }\end{array}$ & - & KX443513 \\
\hline G. arcuatifolia & British Columbia 788 & Canada, British Columbia, 9.VII.1990, Greven s.n. (MO) & KX443549 & KX443511 \\
\hline G. beringiensis & Chukotka 861 & Russia, Chukotka, Penzhigney Bay, 11.VII.1978, Katenin (LE) & - & KX443496 \\
\hline G. beringiensis & Chukotka 1145 & Russia, Chukotka, 23.VII.1976, Afonina s.n. (LE, MW) & KX443538 & \\
\hline G. beringiensis & Chukotka 786 & $\begin{array}{l}\text { Russia, Chukotka, Yanrakynnot, 20.VII.1976, } \\
\text { Afonina s.n. (LE, MW) }\end{array}$ & KX443537 & KX443517 \\
\hline G. decipiens & Bulgaria 84 & Bulgaria, Seregin \& Bocharnikov M-1046 (MHA) & - & KX443497 \\
\hline G. decipiens & Krasnodar 1149 & Russia, Krasnodar Territory, Doroshina 16014 (LE, MW) & KX443520 & - \\
\hline G. elatior & Russia 1212 & Russia, Perm Province, 27.VII.2009, Bezgodov 702 (MHA) & KX443519 & KX443518 \\
\hline G. jacutica & Primorsky 641 & Russia, Primorsky Territory, Ignatov et al. 13-1467 (MHA) & KX443544 & - \\
\hline G. jacutica & Chukotka 782 & Russia, Chukotka, Anadyr, 23.VII.1981, Afonina s.n. (LE) & KX443523 & KX443507 \\
\hline G. jacutica & Chukotka 777 & Russia, Chukotka, Palyavaam, 13.VII.1989, Afonina s.n. (LE) & KX443532 & - \\
\hline G. jacutica & Chukotka 778 & Russia, Chukotka, Palyavaam, 25.VII.1989, Afonina s.n. (LE) & KX443527 & KX443506 \\
\hline G. jacutica & Chukotka 789 & Russia, Chukotka, Palyavaam, 25.VII.1989, Afonina s.n. (LE) & KX443546 & KX443512 \\
\hline G. jacutica & Khabarovsk 27 & Russia, Khabarovsk Territory, Ignatov 97-2013 (MHA) & KX443533 & - \\
\hline G. jacutica & Khabarovsk 748 & Russia, Khabarovsk Territory, Ignatov 97-2013 (MHA) & KX443531 & KX443504 \\
\hline G. jacutica & Taimyr 160 & Russia, Taimyr, Fedosov 05-317 (MW) & KX443530 & - \\
\hline G. jacutica & Taimyr 747 & Russia, Taimyr, Khatanga, Fedosov 11-149 (MHA) & KX443548 & KX443503 \\
\hline G. jacutica & Yakutia 746 & Russia, Yakutia, Orulgan, Ignatov 11-4447 (MHA) & - & KX443502 \\
\hline G. jacutica & Yakutia 148 & $\begin{array}{l}\text { Russia, Yakutia, Suntar-Khayata, Ignatov \& Ignatova } \\
\text { 11-3442 (MHA) }\end{array}$ & KX443526 & KX443501 \\
\hline G. jacutica & Yakutia 48 & Russia, Yakutia, Suntar-Khayata, 14.VII.2003, Zolotov (MHA) & KX443525 & KX443500 \\
\hline G. jacutica & Zabaikalsky 47 & Russia, Zabaikalsky Territory, 21.VII.2005, Afonina s.n. (LE) & KX443534 & KX443499 \\
\hline G. jacutica & Chukotka 791 & Russia,Chukotka, Tanyurer, 10.VIII.1981, Afonina s.n. (LE) & KX443524 & - \\
\hline G. jacutica & Alaska 46 & U.S.A., Alaska, 16.07.1993, Afonina s.n. (LE) & KX443547 & KX443498 \\
\hline G. jacutica & Alaska 781 & U.S.A., Alaska, 14.VIII.1993, Afonina s.n. (LE) & KX443528 & KX443505 \\
\hline G. jacutica & Alaska 783 & U.S.A., Alaska, 14.VII.1993, Afonina s.n. (LE) & KX443529 & KX443508 \\
\hline G. jacutica & Alaska 784 & U.S.A., Alaska, 13.VII.1992, Afonina s.n. (LE) & - & KX443509 \\
\hline G. jacutica & Alaska 785 & U.S.A., Alaska, 14.VII.1993, Afonina s.n. (LE) & KX443543 & KX443510 \\
\hline G. leibergii & Oregon 642 & U.S.A., Oregon, Shevock 27918 (MHA) & KX443541 & KX443515 \\
\hline G. leibergii & California 1264 & U.S.A., California, Shevock 28926 (MHA) & KX443550 & KX443516 \\
\hline G. leibergii & California 29 & U.S.A., California, Shevock 28926 (MHA) & KX443535 & - \\
\hline G. leibergii & California 31 & U.S.A., California, Toren $1460 f$ (MHA) & KX443536 & - \\
\hline G. trichophylla & Spain 1148 & Spain, Kučera 17547 (CBFS, MHA) & KX443521 & - \\
\hline G. trichophylla & California 24 & U.S.A., California, 9.VIII.1989, Ignatov s.n. (MHA) & KX443522 & - \\
\hline
\end{tabular}

